\title{
Brain Structure Morphology After Being Fixated With Ethanol on Electron Microscope
}

\author{
Morfología de la Estructura Cerebral Después de la \\ Fijación con Etanol en Microscopio Electrónico
}

\author{
Arni Kusuma Dewi ${ }^{1}$; Chairul Anwar ${ }^{2}$ \& Yoshihiro Komohara $^{3}$
}

DEWI, A. K.; ANWAR, C. \& KOMOHARA, Y. Brain structure morphology after being fixated with ethanol on electron microscope. Int. J. Morphol., 38(2):305-308, 2020.

SUMMARY: Fixation is one of the processes in preparing histology and pathology. The common material for fixation is buffered formalin including paraformaldehyde. However, the effect of the damaged cells, which is fixed for a long time, causes the research for other fixation materials to become necessary. In addition, paraformaldehyde is also harmful to human body and natural environment. Ethanol is one of the alternative fixation materials, which has been used for two hundred years. It has been used for many purposes, both in routine staining and immunohistochemistry. Nonetheless, no research confirms its effect on the electron microscope. The authors studied the effect of $50 \%$ of ethanol on the cell membrane, organelles, and nucleus of Purkinje cells (Neuron purkinjense) observed on a light microscope and Transmitted Electron Microscope (TEM). Then it was compared to buffered formalin. In the light microscope, it shows that both of fixations have no different effects of the morphology of the cell membrane, cytoplasm, the nucleus of Purkinje cells and the neutrophils. We assume that our $50 \%$ of ethanol concentration is almost the same as BF $10 \%$ in the ability of hardening tissue and color absorption based on the previous study. In TEM, the structure of the cell membrane, organelles, and cytoplasm of Purkinje cell look broken in the cerebellum of $50 \%$ of ethanol except for the nucleus. There was no significant difference diameter of the nucleus. It happened in general because of the shrinkage effect of ethanol. However, the authors recommend using $50 \%$ of ethanol for routine staining.

\section{KEY WORDS: Fixation, Brain, Organelle, Electron Microscope}

\section{INTRODUCTION}

Fixation is one of the processes in preparing histology and pathology. The process in fixation includes the selection of the materials, the concentration used, the method, and the length of time required. It is an area of research that continues to grow because it determines the results as expected.

The use of buffered formalin (BF) as fixation material was found by F. Blum in 1893 (Freudenthal, 1947) and has been used in common practice until now. BF is widely used because of its capability to hardening tissue without considering the size, the solubility in salt, and the capability to be used for various research purposes (Fish, 1896). However, the use of this fixation material for an extended period will cause tissue damage and is not suitable for anatomy museum where which is stored in cold temperatures (Fish; Burke, 1933).
The alternative fixation material that can be used to store specimens for a long period is alcohol. Alcohol has been used as a fixation material since 1922 by Freudenthal. His research was re-summarized in 1947 (Freudenthal). In general, he recommended ethanol as a fixation material for all tissues and cells except for fat staining. The research continues to find the effect of alcohol on each tissue since 1957 (Jarrett \& Hardy, 1957). Then, in 1986, ethanol began to be investigated as fixation material for histochemical staining (Battifora \& Kopinski, 1986).

Ethanol is an alcohol group that is more widely used. Based on several studies, ethanol provides excellent protection for alkaline phosphatase enzymes, coir collagen, DNA, RNA, and lipases (Stafford \& Atkinson, 1948; Jarrett \& Hardy; Su et al., 2004). Based on the research, some modifications of the technique to approve the continuous growth until now. However, none uses an electron microscope.

\footnotetext{
${ }^{1}$ Department of Health, Faculty of Vocational Studies, Universitas Airlangga Campus B, Surabaya, East Java, Indonesia.

${ }^{2}$ Department of Histology, Faculty of Veterinary Medicine, Universitas Airlangga (Campus C), Mulyorejo street, Surabaya, East Java, Indonesia.

${ }^{3}$ Department of Cell Pathology, Faculty of Live Science, Kumamoto University 1-chome-1-1 Honjo, Chuo-ku, Kumamoto, 860-0811, Japan.
} 


\section{MATERIAL AND METHOD}

This study utilized healthy male balb/c mice (Rattus norwegicus) as the experimental animals, weighing 200-300 $\mathrm{g}$. The maintenance and treatment of the experimental animals and the research process have received an ethical conduct certificate from the Ethics Commission of the Faculty of Medicine, Universitas Airlangga. Most of the research were conducted in the Department of Health, Faculty of Vocational Studies, Universitas Airlangga.

The two brain specimens were fixated by immersion for 24 hours at room temperature, each with $50 \%$ of ethanol and $10 \% \mathrm{BF}$. Then, one of the hemispheres was processed with routine coloring for the light microscope and the other for Transmitted Electron Microscope (TEM).

The method by light microscope. The cerebellum of the hemisphere fixated with $50 \%$ of ethanol was cut into $1 \mathrm{~cm}^{3}$ to get embedded in paraffin, cleared dan stained using Hematoxylin-Eosin (HE). The same process for the cerebellum of the hemisphere fixated in $10 \% \mathrm{BF}$.

Method and Analysis by TEM. Both cerebellum of in $50 \%$ of ethanol and $10 \% \mathrm{BF}$ were cut into one $\mathrm{mm}^{3}$ to get fixation to Karnovsky $1 / 2$ for 720 hours at $4{ }^{\circ} \mathrm{C}$. This process took 720 hours because the laboratory of Electron Microscope in Eijkman Institute Universitas Indonesia-Cipto Mangunkusumo Hospitals for later steps must be removed at that time. The
Karnovsky solution was manufactured as a kit by Electron Microscope Science (EMS) in Philadelphia. The authors observed the structure of cell membranes, organelles, and nucleus of the neuron cells. The authors would like to prove if the denaturation effect of ethanol occurred in the nucleus by analyzing the diameter by image raster 3 tool and comparing it with BF.

\section{RESULTS}

There is a different result seen by a light microscope and TEM. In the light microscope. It shows that both of fixation has no different effect of the morphology of the cell membrane, cytoplasm, the nucleus of Purkinje cells (Neuron purkinjense), and no neutrophils are seen, as seen in Figure 1. The cell membrane and cytoplasm stained red and nucleus blue. The neutrophils in both objects were sharp. In TEM, the structure of the cell membrane, organelles, and cytoplasm of Purkinje cells look broken in the cerebellum fixated with $50 \%$ of ethanol, except for the nucleus (Fig. 2).

The authors analyzed the diameter of the nucleus of Purkinje cells in both fixations (Table I). The data were tested for normal distribution with the Shapiro-Wilk test. Because the data were not normal, the authors continued with the Mann-Whitney test with IBM Statistic 20. It showed that there was no significant difference in the diameter between $50 \%$ of ethanol and $10 \% \mathrm{BF}$ treatments ( $>0.05$ ).

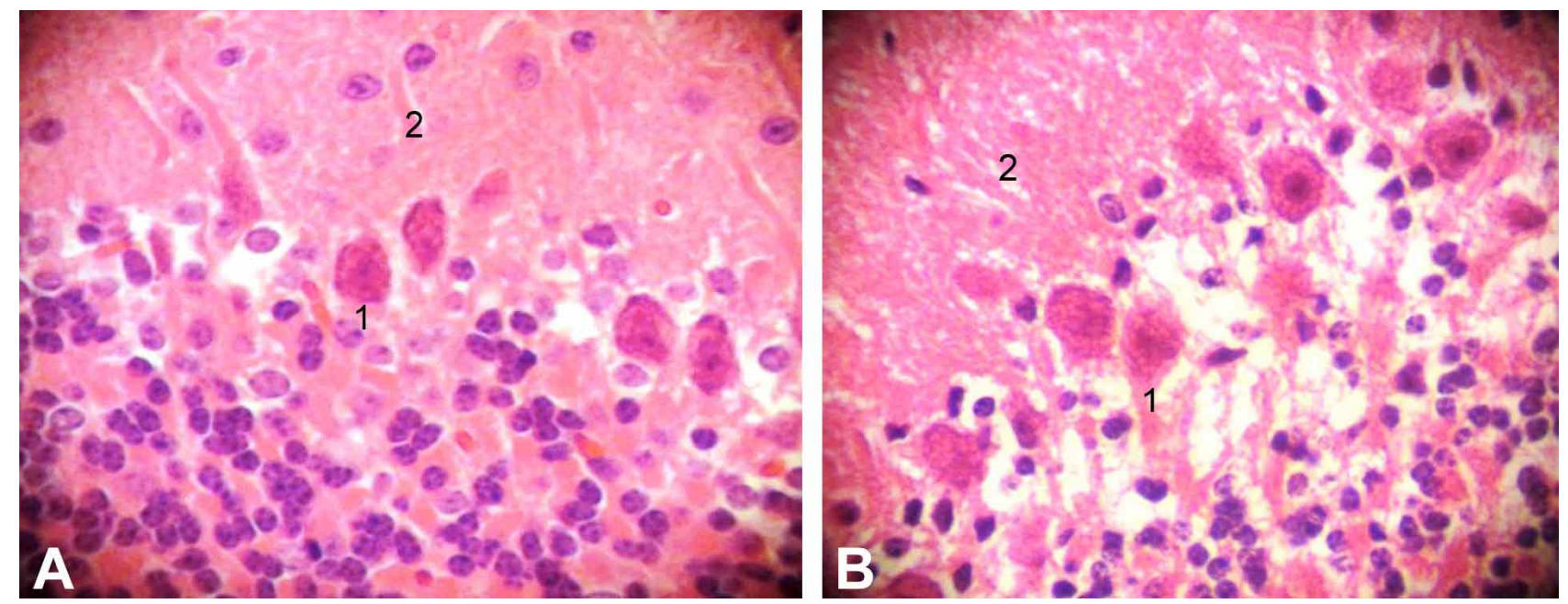

Fig. 1. Cerebellum observed in a light microscope using 400 magnification, HE staining. A. $10 \%$ BF; B. $50 \%$ of ethanol (1. Purkinje cell, considering to cell membrane and nucleus, 2. Neutrophil).

Table I. Description of the Effects of Fixation in TEM.

\begin{tabular}{lll}
\hline Variable & Mean \pm SD $(\mu \mathrm{m})$ & Mann-Whitney test \\
\hline Nucleus diameter on BF fixation & $10086.50 \pm 116.67(\mathrm{n}=2)$ & Asymt Sig $=0.121$ \\
Nucleus diameter on ethanol fixation & $14808.52 \pm 176.27(\mathrm{n}=2)$ & \\
\hline
\end{tabular}



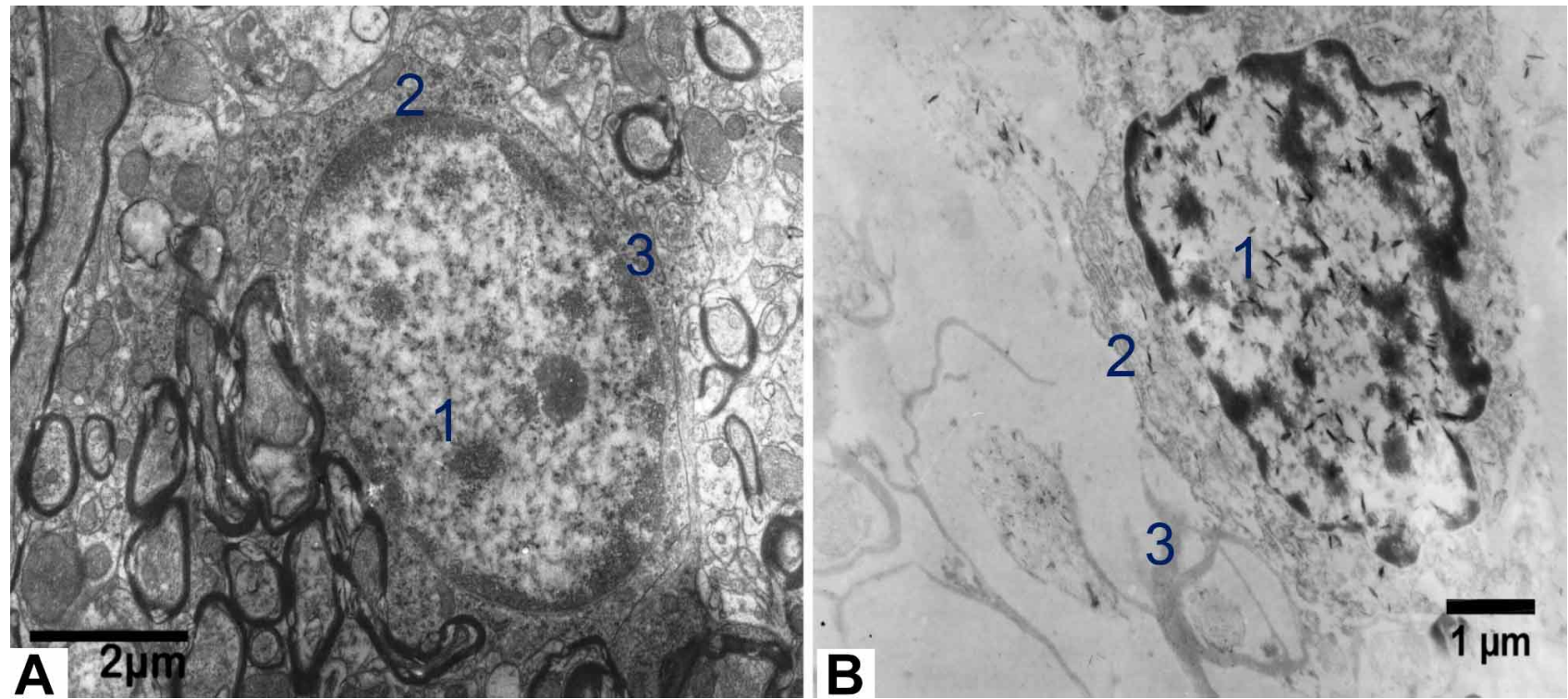

Fig. 2. Cerebellum observed in TEM. A. $10 \%$ BF; B. $50 \%$ of ethanol (1. Nucleus of Purkinje Cells, 2. Cytoplasm (consider to organelles), and 3. cell membrane)

\section{DISCUSSION}

The results of the cerebellum preparation with HE staining between $50 \%$ of ethanol and $10 \% \mathrm{BF}$ were not different. Recent research found that $50 \%$ of ethanol had the capability to hardening tissue to increase contrast in micro-CT (Patzelt et al., 2019). Based on these findings, the authors assume that $50 \%$ of ethanol concentration is almost the same as BF $10 \%$ in terms of their capability of hardening tissue and color absorption. Some studies prefer using ethanol with a concentration of $70 \%$ for routine or immunohistochemical staining (Freudenthal; Jarrett \& Hardy; Schutte et al., 1987; Su et al.). However, there are also those who claim that ethanol shows better results (Battifora \& Kopinski). Therefore, until now, research is still developing to determine the best protocol for ethanol concentration and duration of fixation.

Different results were indicated in the observation with TEM. The cell membrane and organelles in the Purkinje cell cytoplasm at $50 \%$ of ethanol appeared to be degraded even though the storage applied Karnovsky 1/2 at $4{ }^{\circ} \mathrm{C}$ for 720 hours. Research showed that storing specimens in Karnovsky 1/2 more than six months did not cause any damage to the tissue and cell structures (Mount et al., 1997). According to Patzelt et al., the effect of $50 \%$ of ethanol shrinkage is very low, compared to other ethanol fixation concentration. This notion had never been conformed with an electron microscope. However, the previous study showed that the effect of ethanol to damage the morphology would not happen if the ethanol was used as a wash after fixation (Llewellyn-Smith \& Minson, 1992).

The morphology and diameter of the nucleus did not seem to differ between $50 \%$ of ethanol and BF. The authors tried measuring the diameter of the nucleus Purkinje cells and found no difference in the nucleus diameter based on the statistical results. However, preliminary research proved that the RNA yield from brain tissue fixated with BF could only be protected by $5 \%$ on average, compared to $70 \%$ ethanol ( $\mathrm{Su}$ et al.). BF makes a cross-linking reaction between nucleotides and proteins so that less perfect separation and high temperatures can reduce the detected RNA yield ( $\mathrm{Su}$ et al.).

\section{ACKNOWLEDGMENT}

The authors would like to extend their utmost gratitude to the Univesitas Airlangga and Eijkman Institute Universitas Indonesia-Cipto Mangunkusumo Hospitals to support the facilities. The authors also would like to acknowledge to Department of Cell Pathology and the Department of Histology, the Faculty of Live Science, Kumamoto University for supporting them with the knowledge. 
DEWI, A. K.; ANWAR, C. \& KOMOHARA, Y. Morfología de la estructura cerebral después de la fijación con etanol en microscopio electrónico. Int. J. Morphol., 38(2):305-308, 2020.

RESUMEN: La fijación es uno de los procesos en la preparación de muestras para histología y patología. El material más común para la fijación es la formalina tamponada. Sin embargo, el daño a las células que se mantienen en formalina durante mucho tiempo, hace necesario buscar otros materiales de fijación. Además, el paraformaldehido también es perjudicial para el cuerpo humano y el medio ambiente natural. El etanol es uno de los materiales de fijación alternativos que se ha utilizado durante muchos años, con diversos objetivos, tanto en la tinción de rutina como en la inmunohistoquímica. Sin embargo no se ha confirmdo su efecto con microscopio electrónico. Los autores estudiaron el efecto del $50 \%$ de etanol sobre la membrana celular, los orgánulos y el núcleo de las células de Purkinje observados en un microscopio óptico y un microscopio de transmisión electrónico (TEM). Luego se comparó con la formalina tamponada. En el microscopio óptico se observó que ambas fijaciones no tienen efectos diferentes a la morfología de la membrana celular, el citoplasma, el núcleo de las células de Purkinje y los neutrófilos. Suponemos que nuestra concentración de $50 \%$ de etanol es casi la misma que BF $10 \%$ en la capacidad de endurecer el tejido y la absorción de color según el estudio anterior. En TEM, la estructura de la membrana celular, los orgánulos y el citoplasma de la célula de Purkinje presentaban daño en el cerebelo con un $50 \%$ de etanol, a excepción del núcleo. No hubo diferencia significativa en el diámetro del núcleo. En general lo anterior se debió al efecto de contracción del etanol. En conclusión los autores recomiendan usar 50\% de etanol para la tinción de rutina.

PALABRAS CLAVE: Fijación; Cerebro; Organelo; Microscopio electrónico.

\section{REFERENCES}

Battifora, H. \& Kopinski, M. The influence of protease digestion and duration of fixation on the immunostaining of keratins. A comparison of formalin and ethanol fixation. J. Histochem. Cytochem., 34(8):1095100, 1986.

Burke, F. V. The $\mathrm{pH}$ of formalin - A factor in fixation: adjustment and stabilization of the hydrogen ion concentration of formalin solutions. Am. J. Pathol., 9(6):915-20, 1933.

Fish, P. A. The use of formalin in neurology. Trans. Am. Microsc. Soc., 17:319-30, 1896.

Freudenthal, W. Recent Advances in Clinical Pathology. London, Churchill, 1947. pp.388.

Jarrett, A. \& Hardy, J. A. The value of alcohol for fixation of skin. Stain Technol., 32(5):225-33, 1957.

Llewellyn-Smith, I. J. \& Minson, J. B. Complete penetration of antibodies into vibratome sections after glutaraldehyde fixation and ethanol treatment: light and electron microscopy for neuropeptides. $J$. Histochem. Cytochem., 40(11):1741-9, 1992.

Mount, S. L.; Schwarz, J. E. \& Taatjes, D. J. Prolonged storage of fixative for electron microscopy: effects on tissue preservation for diagnostic specimens. Ultrastruct. Pathol., 21(2):195-200, 1997.
Patzelt, M.; Mrzilkova, J.; Dudak, J.; Krejci, F.; Zemlicka, J.; Karch, J.; Musil, V.; Rosina, J.; Sykora, V.; Horehledova, B.; et al. Ethanol fixation method for heart and lung imaging in micro-CT. Jpn. J. Radiol., 37(6):500-19, 2019.

Schutte, B.; Reynders, M. M.; Bosman, F. T. \& Blijham, G. H. Effect of tissue fixation on anti-bromodeoxyuridine immunohistochemistry. $J$. Histochem. Cytochem., 35(11):1343-5, 1987.

Stafford, R. O. \& Atkinson, W. B. Effect of acetone and alcohol fixation and paraffin embedding on activity of acid and alkaline phosphatases in rat tissues. Science, 107(2776):279-81, 1948.

Su, J. M. F.; Perlaky, L.; Li, X. N.; Leung, H. C. E.; Antalffy, B.; Armstrong, D. \& Lau, C. C. Comparison of ethanol versus formalin fixation on preservation of histology and RNA in laser capture microdissected brain tissues. Brain Pathol., 14(2):175-82, 2004.

\section{Corresponding author:}

Arni Kusuma Dewi

Department of Health

Faculty of Vocational Studies

Universitas Airlangga (Campus B)

Jalan Dharmawangsa Dalam No. 28-30

Surabaya

East Java

INDONESIA

Email: arni-k-d@vokasi.unair.ac.id

Received: 21-05-2018

Accepted: 24-07-2019 